\title{
Sustainable economy of the ecological footprint: economic analysis and impacts
}

\author{
S. H. Shakir Hanna \& I. W. Osborne-Lee \\ Texas Gulf Coast Environmental Data (TEXGED) Center, \\ Chemical Engineering Department, Prairie View A\&M University, USA
}

\begin{abstract}
The ecological footprint is an important measure in calculating the human demands and impacts on our global environment. In this respect the ecological footprint is a function of all the parameters that interact between the power of ecosystem productivity and human interactions and activities on a particular ecosystem or the demand from that ecosystem. The present paper will cover and analyze the ecosystems productivity and the human demand from the ecosystems. It will produce comprehensive analyses in measuring the possibility of capabilities of the ecosystems to provide goods and services to the human beings on our planet Earth. Further, the paper will discuss the models that can be used in measuring the sustainability of ecosystem and what we should be doing to maintain the Earth healthy ecosystems.

In this respect, the paper will assess and introduce a comprehensive model that can describe the status of our ecosystems productivities and the impacts of human population on the plant Earth. Furthermore, the paper will provide some answers to the human issues, further warning to the current trend in use and abuse of our natural ecosystems and what will be expecting from these ecosystems to provide the human needs in response to the current use of our global ecosystems. Finally, it will conclude and setup several recommendations to save our Planet Earth from the irreversible impacts of human beings on the ecosystems and our global environment.
\end{abstract}

Keywords: economic analysis, ecological footprint (EF), impacts, global biological capacity (GBC), global biological demand (GBD), global deficit capacity, global ecological capacity $(G E C)$, sustainability index, maintenance index. 


\section{Introduction}

The term Ecological Footprint has been introduced by Wackernagel and Rees [1]; Wackernagel et al. [2]. However, the authors are defining Ecological Footprint (EF) as a measure of the status of the global ecosystems' ability to provide service and goods to all human beings who are living on the Earth. Further, the global ecosystems provide for the needs of all other organisms that exist on the planet and, in consequence, enable the goods and services to be provided to human beings. Therefore, the global ecosystems provide for the needs of all living beings on the Earth including the human beings.

In light of the above definition, we need to discuss in a broader sense what is actually happening on the planet Earth now. In previous ages we the human population were not faced with several aspects of shortage in resources such as water, productive soil to produce food, energy, raw materials, clean air, and so on which is now raising a question of great importance to human beings: Can the Earth continue to cover the needs of its growing human population? We must ask ourselves where we are going and how to maintain our global environment to maintain and sustain our existence. Can we maintain our existence? How can we maintain the productivity of our global ecosystems at a level to sustain our existence and standard of living in the light of our growing demands?

Warnings have been seen about the growth of human populations and their needs (Wackernagel [3], Rees [4], Lenzen et al. [5] and Grazi et al. [6]). These warnings have indicated that the growing population has affected the global ecosystems. In a recent conference of Food Security in Rome, Italy on November 16-18, 2009, the delegates of the countries attending the conference have indicted that the world is facing a shortage of food as an important one item of the global ecosystem service to human beings. Zhao et al. [7] have indicated that humans have had a considerable impact on the Earth associated with population increase and economic development. They indicated also that humans are faced with a series of disturbing contradictions and trends among the natural resources, the environment, and the economy, such as rising population growth, resources depletion and environmental deterioration. These trends are pointing to adverse impacts and the need for considering the importance of sustainability in maintaining globe natural resources. Otherwise, the human race will face shortage of these natural resources with serious consequences for the global economy.

Moderate United Nation Environmental Program (UNEP) [8] scenarios suggest that if current population and consumption trends continue, by the middle of the next decade, we will need the equivalent of two Earths to support us, and of course, we only have one. Turning resources into waste faster than waste can be turned back into resources puts us in global ecological overshoot, depleting the very resources on which human life and biodiversity depend.

The challenge of maintaining the Earth's ecology and sustaining the regeneration of its resources is an enormous effort that requires collaborative work between government agencies, localities and human beings themselves on a global scale. Without these efforts, global ecosystems could be facing a 
collapse leading to global chaos. In this respect, sustainability whether nationally, regionally, or globally requires that natural resources not be exploited beyond the renewable limits.

EF is a broad measure of resource use that highlights where consumption is exceeding environmental limits. The Best Foot Forward Company in the United Kingdom [9] uses the ecological footprint methodology to help businesses and other organizations measure, monitor and reduce their impacts.

The present paper will assess the status conditions of our global Earth, predict the Global Biological Capacity (GBC), Global Biological Demand (GBD) and introduce a comprehensive model that can describe the status of our ecosystems in term of productivity and the impacts of the human population on planet Earth. Furthermore, the paper will provide some answers to the human issues, warning on the current trend in overuse and abuse of our natural ecosystems and what should be expected in terms of the ability of the Earth's ecosystems to provide for human needs in response to the current use of our global ecosystems. The paper concludes with recommendations for avoiding irreversible impacts of human beings on the ecosystems and our global environment.

\section{Material and methods}

Data used in this paper were collected from different data set of series available on the web sites of the World Research Institute (WRI)-Earth-Trends [10], the World Bank [11], Food and Agricultural Organization (FAO) [12, 13], United Nation Development Program, World Wildlife Fund (WWF) [14-16] and the Global Footprint Network [17, 18]. The data were analyzed using regression, correlation, and statistical methodologies using Sigma Plot Software [19].

The Maintenance Index (MI) or (Sustainability Index) is a percentage of the total GBC (i.e. total availability or supply) in global hectares to the total GBD (i.e. consumption or demand) in global hectares from the Earth. This index explains the ability of the Earth to regenerate natural resources. In other words, it explains the status of the Earth in providing goods and services to the needs of the human population. The GBC is defined as the ability of the Earth to produce renewable natural resources in terms of global hectare/capita. GBD is defined as the resources consumption by human beings in terms of global hectare/capita. It is important to indicate the calculations of Total GBC and Total GBD are the most important factors in the calculations of indices that have been discussed in this paper. Other terms used in calculations are Cropland Footprint (CF) in billion global hectares, Grazing Land Footprint (GLF) in billion global hectares, Forest Ground Footprint (FGF) excluding fuel wood in billion global hectares, Fish Ground Footprint (FF) in billion global hectares, Total Energy Footprint (TEF) in billion global hectares, Built-up Land (BL) in billion global hectares and Global Deficit Capacity (GDC) in billion hectares. The formulae for calculating the following indices are as follows:

$$
\begin{gathered}
\text { MI Index }=\mathrm{GBC} / \mathrm{GBD} * 100 \\
\mathrm{GBC}=\mathrm{CF}+\mathrm{GLF}+\mathrm{FGF}+\mathrm{FF}+\mathrm{TEF} \mathrm{BL} \\
\mathrm{GBD}=\mathrm{CF}+\mathrm{GLF}+\mathrm{FGF}+\mathrm{FF}+\mathrm{TEF} \mathrm{BL} \text { consumed }
\end{gathered}
$$




$$
\mathrm{GDC}=\mathrm{GBC}-\mathrm{GBD}
$$

These estimates are calculated according to several authors of ECOTEC-U.K group [20] and Wackernagel et al. [21] using the following: 1) Net primary Productivity (NPP); 2) Growing crops for food, animal feed; 3) Fibber and oil; 4) Grazing animals; 5) Wood from forest; 6) Fishing from marine and freshwater; 7) Infrastructure for housing and building transportation and electrical power; 8) Burning for fuel in $\mathrm{CO}_{2}$ emissions. These calculations depended on the governmental UN data series from the World Bank. These calculations were converted into billion hectares from the global sized hectares.

Predictions of Total GBC and Total GBD for the Earth in the next decades were calculated to show the impact of growth of the world population on the basis of annual data from a series of years 1960 to 2008 for almost 48 years of published data. The predications for the years 2009 to 2050 were analyzed using correlation and regression lines (Tables 1 and 2).

\section{Importance of understanding ecological footprint}

Ecological footprint as described above is the measure to analyze the human needs from the Earth in the form of resources that provide services and goods for consumption by human beings. Currently, the human population carrying capacity is exceeding the resources of the Earth $[8,20]$. It is important to calculate the human population carrying capacities from each nation on this Earth against its resources and to create an Ecological Accounting System (EAS) that gives each country an ecological measure indicating how each country stands against its resources. This accounting system can be of a control of a nation and its impact on whole global environment (i.e. the maintenance indicator or parameter for the nation in global ecosystems). This is a scenario to explain how to close the gap between the Earth's resources and the human basic needs from this Earth. In general in our life we are at the level of individuals calculating our earning and expenses (i.e. income against our spending). If we have a positive balance that means we are not in debt to the others. The same will be the scenario against the Earth resources. What are the credits that each country has against its boundaries' resources exploitations? We have to think ecologically about the natural resources that we have to provide us with services, products, and the natural resources that we consume. We have to consider how are we able to save or conserve these resources for the next generations. Then we have to think about how we can trade our surplus from the resources to the others. It is imperative in this thinking process to consider the welfare of human beings over the generation of rapid wealth against humanity. At the same time, we have to regulate human behaviour in exploiting the natural resources in order to save the Earth for the next generations. The next section presents the most important factors that determine the human populations' needs and their impacts on global ecosystems of our planet Earth. 


\section{Impacts of the human population on food security and natural resources of the world}

The human population has increased to the point that the Earth cannot support the human population with the food that is needed to survive. This conclusion can be explained in (Tables 1 and 2). In the tables, the need for each human being living on this Earth is estimated by about 2000 calories per day as an estimation of US (US Department of Health and Human Services and US Department of Agriculture, 2005) [22]. The total number of human beings who are living on this Earth is 6.69 billion people (Table 1) in the year 2008 . Therefore, the daily need for the Earth's populations is about 13.85 trillion calories per day and their annual need is about 5044.30 trillion calories per year. Accordingly, what are the sources of all these calories? These calories would come from crops, meat, vegetables and others sources on the Earth's surface or below sea. The question is whether the Earth's resources can support the populations who are living on this Earth. The most useful resources from the Earth to produce the needed calories are the arable-cropped lands, forest ecosystems, water resources, grazed lands, converted as carbon footprint, fishing ground footprint, and built-up lands. It is estimated that the global land of the Earth in 2008 that can produce the food required to keep every human being in a status of normal health is requiring 2.81 global hectare/capita (i.e. the demand 18.80/6.69). However, 2008, it is estimated 1.79 hectare/capita (i.e. 12.0/6.69) is the biological capacity of the Earth to provide us with the calories as calculated from Table 1. This means that we are in shortage for producing enough calories to cover all human beings on this Earth. The current shortage in global hectare per/capita is equal to $37 \%$ in 2008 (Fig. 1). In this respect, the maintenance

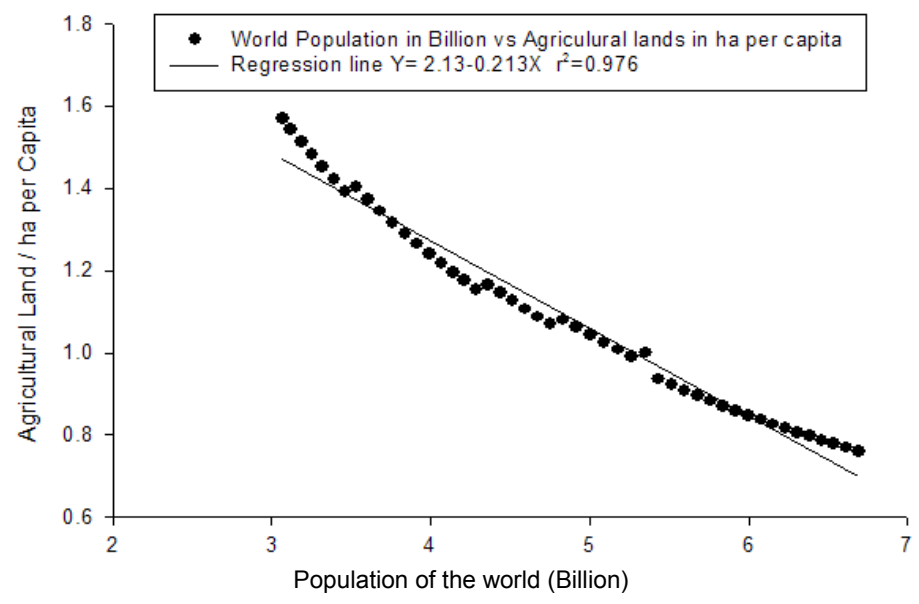

Figure 1: Relationship between the world's human population in billion and agricultural lands per capita. 


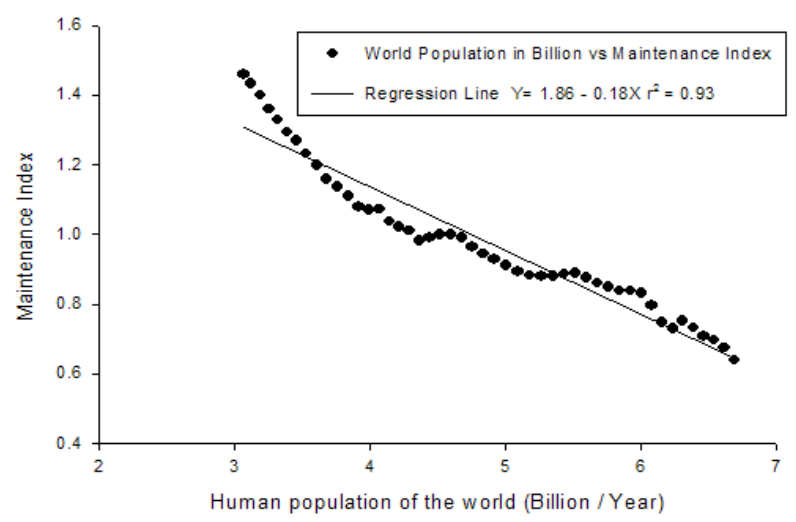

Figure 2: Relationship between the human population of the world and maintenance index (GBC in billion global ha/GBD in billion global ha).

index of the Earth as we suggested is the total GBC of the Earth/total GBD or the EF means that a decline in resources to support the existing human beings and consumption of the Earth as a percentage of the measure of how our Earth needed to be protected and to look to further conservation of the natural resources to meet the needs of human beings (Fig. 2 and Tables 1 and 2). From the regression diagram, it is expected that the when the population reaches about 9.23 billion, the maintenance index of sustainability will reach $0.19(0.27$ global hectare per capita). It is apparent from the regression model of the human population and global biological capacity resources (Fig. 3) that we can come to

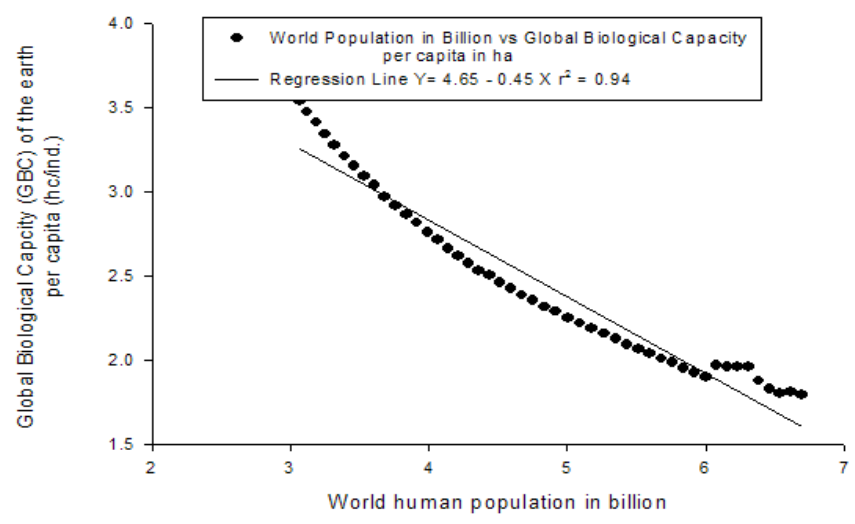

Figure 3: Relationship between the world's human population in billion and global biological capacity of the Earth per capita (ca/ind). 


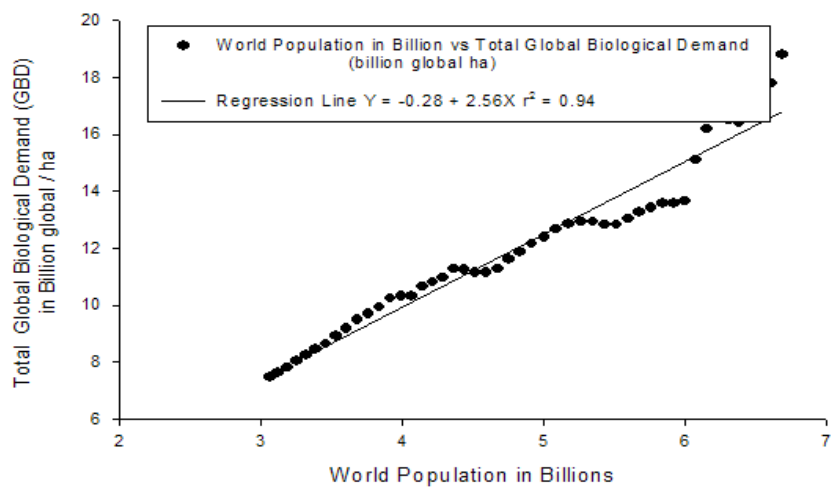

Fig 4. Relationship between world population in billion and global biological demand (GBD) in Billion global hectare

Figure 4: Relationship between the world's population in billion and global biological demand in billion global hectare.

conclude that the future of our global biological capacity on the current trend of use is about to 0.4965 hectare /capita when the population density of the globe reaches 9.23 billion in year 2050 as the projected estimates indicated in Table 2. This future generation. On the other hand, the demands from the Earth will increase to reach 23.36 global billion hectares in year 2050. This means the demands will increase to reach 2.53 global hectare/capita. Respectively, the human population will run deficit against the Earth's resources by about 2.18 hectare/capita. Also, the GDC against the surface area will reach 175\% (Figs. 4, 5 and 6). We believe it is alarming that humans should control the abuse of the Earth's current natural resources.

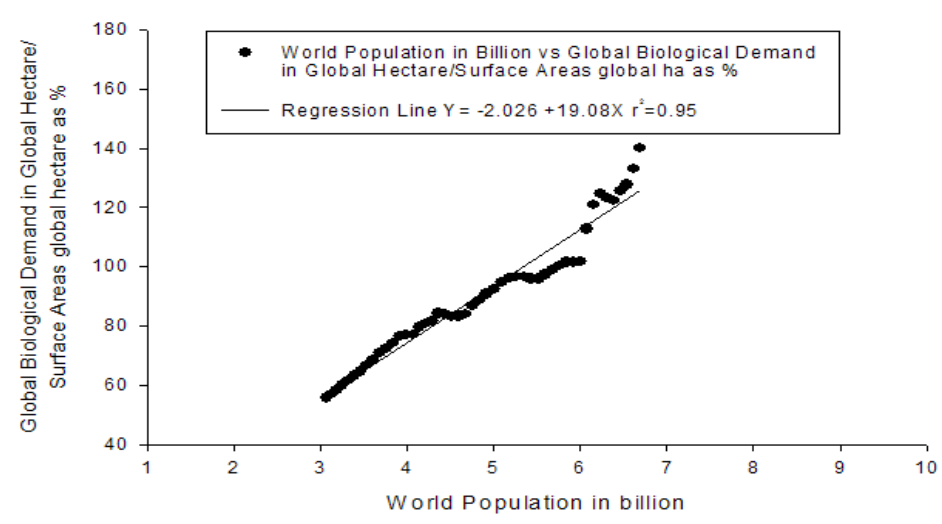

Figure 5: Relationship between the world's population in billion and global biological demand in hectare/surface areas global hectare as \%. 


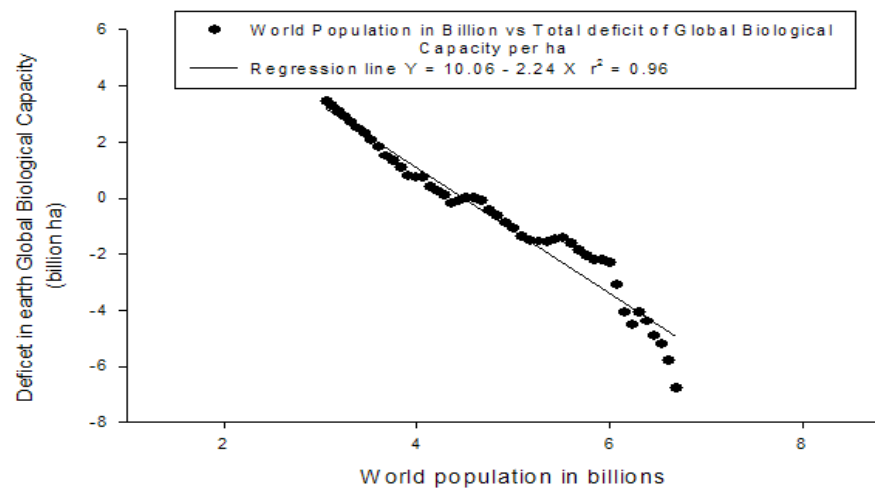

Figure 6: Relationship between the deficit in the Earth's global biological capacity in billion hectare and the world's population in billion people.

\section{Economy and concept of emerging of ecological footprint}

Emerging concept of ecological footprint issue has been developed over the past twenty five years since 1988 (Odum [23, 24]). This emerging concept as indicated from its name is the works of nature and the activities nature of human beings in producing products and services. On the other hand, humans are demanding from the nature the raw materials, crops, energy, services and consumption to survive. This concept can be developed in a model in economic analysis using the money factors and values of the natural resources and the service of these resources. Accordingly, to the model in the diagram (Fig. 7) below explains the flow of natural resources in the ecosystems and its relationship to the global economy. Also, this figure shows the interrelationships between human activities, their ecological footprint, maintenance of natural resources (i.e. renewable and non-renewable resources) and their impact on global economy.

The model in Fig. 7 indicates the relationships between aspects of natural resources (renewable and non-renewable), ecological footprint, human population, space and time and economy. It is important to take into consideration the factor of space and time as a value in the evaluating the economy of natural resources that we are exploiting including the rate of speed of the use of these natural resources.

According to economic analysis taking into consideration the economy model that predict the value and prospective of natural resources including the in the calculation the human impacts, it is, important to realize the relationship between the speed of increase in population worldwide and the speed of the renewability 
อ

棬

응.

롱요

惫.

可

矢和

응

in 웅

홍

홍요

政

言高

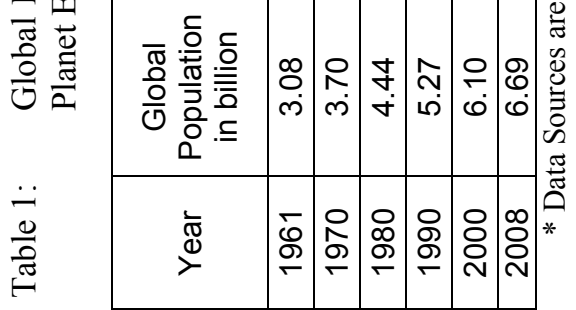

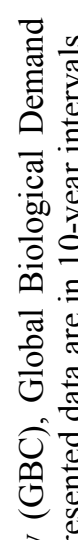

8 8

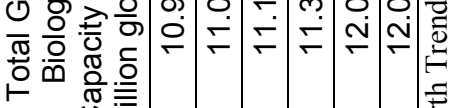

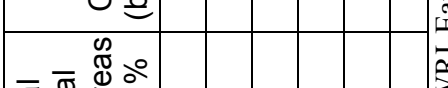

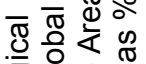

造

क्षे

0.

छึ

.00 0

응

党

సี

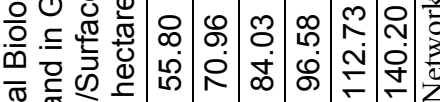

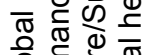

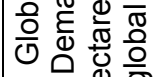

需

뜽 음

음응

贾 은 응 응

윰

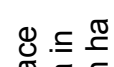

西

突安

ஓ্লি

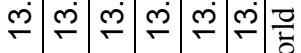

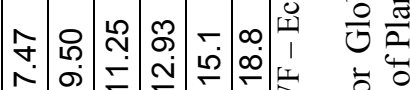

के

웅

总

可

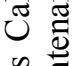

$\stackrel{\mathscr{\Xi}}{\Xi} \cdot \stackrel{\Xi}{\Xi}$

$\stackrel{\pi}{>} \sum$

믈

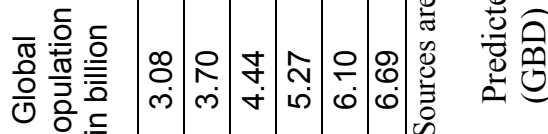

$\underset{\ddot{0}}{\ddot{0}}$

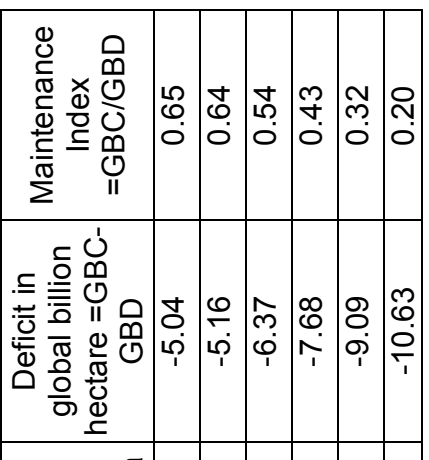

Оิ

즁 ত্

은 응 뭉

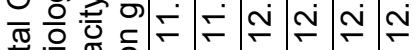

믄 $\frac{0}{\pi}$

$-\stackrel{\infty}{\infty} \underset{\infty}{\infty}$

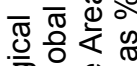

훙응 $₫$

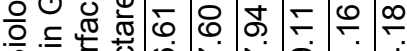

商

त $\frac{\pi}{\circ} \frac{\pi}{\pi}$

은 웡 융

핌

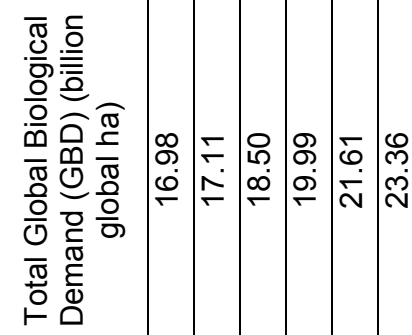

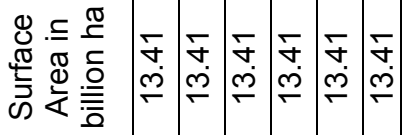

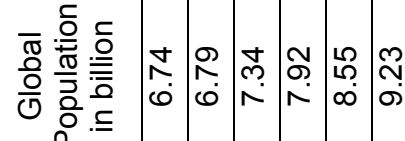

¿

WIT Transactions on Ecology and the Environment, Vol 144, (C) 2011 WIT Press

www.witpress.com, ISSN 1743-3541 (on-line) 


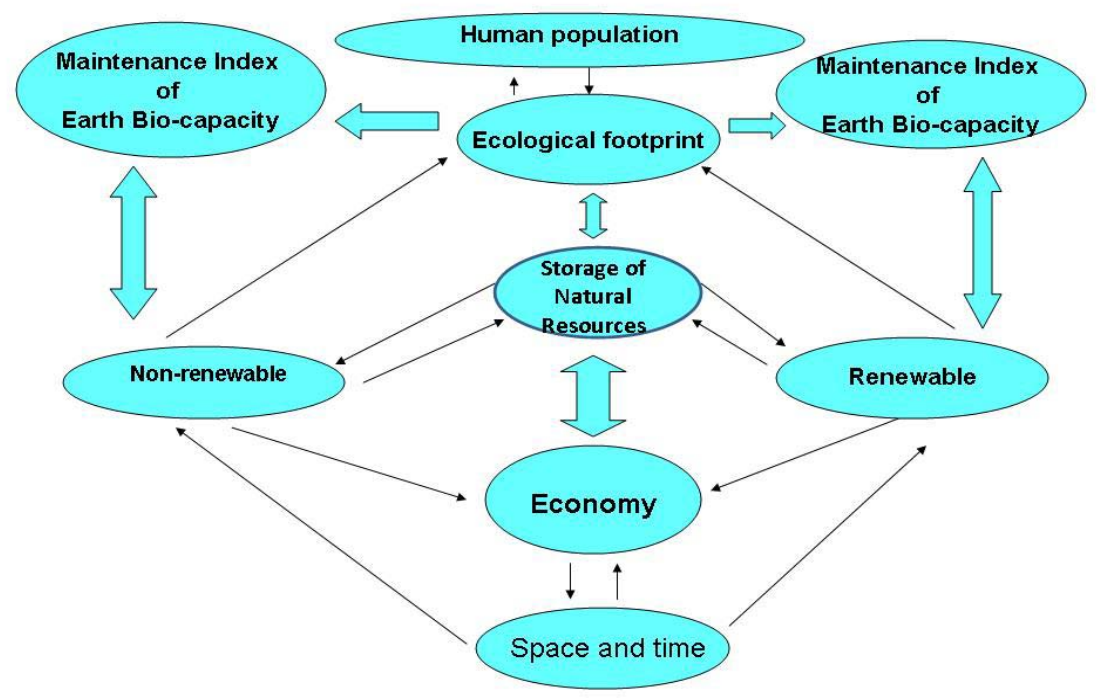

Figure 7: Diagram show the inter-relationships between natural resources, Ecological Footprint and Global Economy.

of the resources. In other words, what is the speed of growth of renewability resources against the growth of human beings? The renewability of the natural resources will become steady or experience a little growth in the next decades and in the opposite the human population will increase in alarming annual rate at $1.1 \%$.

The EF "accounts for the flows of energy and matter to and from any defined economy and converts these into the corresponding land/water area required from nature to support these flows" Wackernagel and Rees [1].

\section{The challenges facing our global ecosystem}

In the light of the above analysis, the human beings are faced with a lot of challenges not only from economic point of view (i.e. unemployment, funding of projects, funding of disastrous that are happenings in the world, financial recovery ...etc) but also from ecological issues. These ecological issues are:

$>$ Lack of arable lands that are used for production of food, forestry woods, pastures and animal breading for producing milk and other meet products for human nutrition

$>$ Conserve the wild-land habitats and to be set aside to preserve large and small preserves for the use of the next generation and to maintain the biological species diversity. In this respect, the plant species, animal species and natural ecosystems cannot utilize the Earth lands 
extensively as human beings doing for exploitation the Earth natural resources in an alarming rate. Preserving the current biological species diversity of plants and animals will require leaving sizable landscape areas with light utilization from human beings or non-utilization in order to support the life cycle of the Earth.

$>$ It is important to use the efficient technology to save our planet Earth and continue reuse the materials that we exploit from the natural resources several times to ensure the sustainability of the Earth.

$>$ The success of our economy should be based on the ecological sustainability of our Earth. In other words, the global economy should adhere to sustainability of Global Ecological Capacity (GEC) of global Earth as a measure of equalization between the total Global Biological Demand (GBD) from the Earth in global hectare/capita and total Global Biological Capacity (GBC) of the Earth in global hectare/capita. This means that human beings will sustain the Earth ecological budget. The data in the Table 2 showed that year 1981 is year that had GBC equal to GBD.

$>$ The most important challenge of all the above is human beings controlling themselves in sustain population numbers within the acceptable limits that the Earth can support (i.e. maintaining the ecological budget of the Earth without overloading or stressing these natural resources). This will take more efforts from the governments, non-government organizations (NGO) and individuals to sustain the Earth bio-capacity. Otherwise, the Earth returns its action (i.e. exposure to lack of food, famines, diseases, global climatic disasters on the human race...etc).

$>$ The education is the most crucial element in the above challenges to educate the public of the issue of maintaining the Earth ecological capacity.

\section{Discussion}

Ecological footprint is an accountant and economical measure that can describe the balance, surplus and deficit between the global productivity (i.e. renewability of natural resources global biological capacity in global million hectare) and the human demands from the Earth resources (i.e. global biological demands or consumption in global billion hectares). Considerable attention recently to the methodologies in calculating ecological footprint and importance of this issue is discussed Zhao et al. [7], ECOTEC-U.K. [20] and Wackernagel et al. [21]. There are several scientists and researchers have considerable oppositions or weaknesses to the ecological footprint accounting ECOTEC-U.K [20]. These oppositions and concerns are 1) Measure of sustainability; 2) Only $\mathrm{CO}_{2}$ emission calculation included in the ecological footprint rather than the other greenhouse gases; 3) Human welfare is a multi-dimensional issue and a single index oversimplifies; 4) Ecological footprint index is including quantitative rather qualitative issues; and 5) the sequestration of $\mathrm{CO}_{2}$ in the ocean. However, in 
spite of these weaknesses, the authors are considering the ecological footprint as a sensitive measure that can be important to allow the decision makers to take care about the natural resources and to start thinking in matter of conserving natural resources in spite of the human pressure. From the above analysis, I found that Earth will only support in approximately $25 \%-30 \%$ of the total population of the globe in year 2050 and it will run a deficit of the total global biological capacity about $80 \%$ of the Earth in a conservative assumption. This conclusion will indicate an alarming to the leaders of the world, Non Governmental Organization and Government Agencies, United Nation with all its agencies to take appropriate actions to conserve world resources for the future generations. Otherwise we are facing severe competition on these natural resources (i.e. renewable and non-renewable), and none can predict the consequences of this situation. It is important that leaders of the world to concentrate on education of the population about the disastrous consequence of human population growth against the regenerative speed process of the biological capacity of the ecosystems to sustain the demand with production of these resources.

Generally, it is important to discuss the issue of energy conversion of global hectare to quantitative measure (i.e. Energy Conversion Factor per global hectare in energy units). This will be my next analysis of conversion of hectare land to energy use and then modelling for the global bio-capacity against global demands for energy from the Earth.

\section{Conclusion}

This paper indicates an alarming warning about the trends in Global Biological Capacity (GBC) [i.e. regenerative capacity of Earth] and Global Biological Demand (GBD) [i.e. global consumption from the Earth]. In addition, this paper shows the trends in the deficit regenerative capacity of the Earth. The current deficit regenerative capacity of the Earth is about $40 \%$ and continues to be $50 \%$. From this study, it is found that 1981 is the year that world has a break even point between the GBC to be equivalent to GBD. In this respect, we have to monitor the world status and condition of the balance between the GDB and GBC. This will not be accomplished without the collaborative efforts of the all individuals, governmental and non governmental agencies, and global world organizations as United Nations.

\section{References}

[1] Wackernagel, M. \& Rees, W., Our Ecological Footprint: Reducing Human Impact on the Earth. Gabriola Island, BC, and Philadelphia: New Society Publishers, 1996.

[2] Wackernagel, M., Onisto, L., Bello, P., Linares, A. C., Falfan, I. S. L., Garcia, J. M., Guerrero, A. I. S. \& Guerrero, M. G. S., National natural 
capital accounting with the ecological footprint concept. Ecological Economy vol. 29, pp. 375-390, 1999.

[3] Wackernagel, M., Ecological Footprint and Appropriated Carrying Capacity: A Tool for Planning Toward Sustainability, in School of Community and Regional Planning. vol. Ph.D. thesis: The University of British Columbia. Vancouver, Canada., 1994.

[4] Rees, W. E., Ecological footprints and appropriated carrying capacity: what urban economics leaves out Environment and Urbanisation vol. 4, pp. 121130,1992

[5] Lenzen, M., Hansson, C. B. \& Bond, S., On the bioproductivity and land disturbance metrics of the Ecological Footprint. Ecological Economics vol. 61, pp. 6-10, 2007.

[6] Grazi, F., Bergh, J. C. J. M. V. D. \& Rietveld, P., Welfare economics versus ecological footprint: modeling agglomeration, externalities and trade. Environmental and Resource Economics vol. 38, pp. 135-153, 2007.

[7] Zhao, S., Li, Z. \& Li, W., A modified method of ecological footprint calculation and its application Ecological Modelling, vol. 185 pp. 65-75, 2005.

[8] UNEP, A Planet in Ecological Debt. Arendal Maps and Graphics Library:http://maps.grida.no/go/graphic/a-planet-in-ecological-debt 2009.

[9] http://www.bestfootforward.com/

[10] WRI, EarthTrends Environmental Information, World Resource Institute: WRI - http://Earthtrends.wri.org/, 1960-2005.

[11] WorldBank, Data Series and Research, The World Bank organization. www.worldbank.org1960-2008.

[12] FAO, FAOSTAT (Food and Agriculture Organization, United Nations, Rome). 2008.

[13] FAO, FAOSTAT FAO Statistical Database FAO www.fao.org, 1960-2008.

[14] Jenkins, M., Jakubowska, J., Gaillard, V., Groombridge, B., Wackernagel, M., Monfreda, C., Deumling, D., Gurarie, E., Friedman, S., Linares, A. C., Sánchez, M. A. V., Falfán, I. S. L., Loh, J., Randers5, J. \& Monfreda, C., Living Planet Report 2002, World Wildlife Fund (WWF), www.panda.org, WWF International. Avenue du Mont-Blanc, CH-1196 Gland, Switzerland 2002.

[15] Humphrey, S., Chapagain, A., Bourne, G., Mott, R., Oglethorpe, J., Gonzales, A., Atkin, M., Loh, J., Collen, B., McRae, L., Carranza, T. T., Pamplin, F. A., Amin, R., Baillie, J. E. M., Goldfinger, S., Wackernagel, M., Stechbart, M., Rizk, S., Reed, A., Kitzes, J., Peller, A., Niazi, S., Ewing, B., Galli, A., Wada, Y., Moran, D., Williams, R., Backer, W. D., Hoekstra, A. Y. \& Mekonnen, M., Living Planet Report 2008, WWFWorld Wide Fund, www.panda.org, WWF International Avenue du MontBlanc 1196 Gland, Switzerland2008.

[16] WWF-The Global Conservation Organization, H. S., http://www.panda.org/, E.F.A.A. \& news_facts/publications/ living_planet _report/ footprint. 
[17] Kitzes, J., Galli, A., Rizk, S., Reed, A. \& Wackernagel, M., Guidebook to the National Footprint Accounts: 2008 Edition, Global Footprint Network, http://www.footprintnetwork.org/, Oakland, CA 94607-3510, USA2008.

[18] Ewing, B., Reed, A., Rizk, S. M., Galli, A., Wackernagel, M. \& Kitzes, J., calculation methodology for the national Footprint accounts, 2008 Edition, Global Footprint Network. http://www.footprintnetwork.org, Oakland, CA 94607-3510, USA 2008.

[19] Www.spssscience.com/sigmaplot version 82002

[20] ECOTEC-U.K., Ecological Footprint, European Parliament, Directorate General for Research, Directorate A, The STOA Programme March, 2001.

[21] Wackernagel, M., Schulz, N. B., Deumling, D., Linares, A. C., Jenkins, M., Kapos, V., Monfreda, C., Loh, J., Myers, N., Norgaard, R. \& Randers, J., Tracking the ecological overshoot of the human economy, Proceedings of The National Academy of Sciences of the United States of America (PNAS), vol. 99, pp. 9266-9271, 2002.

[22] U.S. Department of Health and Human Services and U.S. Department of Agriculture, Dietary Guidelines for Americans, , 6th ed, 2005 p. $71+$ IV $\mathrm{PP}+$ Appendix

[23] Odum, H. T., Environment Accounting: Emergy and Environment Decision Making. John Wiley, New York, 1996.

[24] Odum, H. T., Self-Organization, Transformity, and Information. Science, vol. 242, pp. 1132-1139, 1988. 